\title{
Mütrágyázás hatása a sáfrányos szeklice (Carthamus tinctorius L.) elemfelvételére
}

\author{
KÁDÁR IMRE \\ MTA Talajtani és Agrokémiai Kutatóintézet, Budapest
}

\section{Bevezetés és irodalmi áttekintés}

A hazai irodalom nem bővelkedik e növény taglalásában, pl. a legtöbb növénytermesztési tankönyv alig említi. Talán célszerü CSERHÁTI (1901) sorait idézni az okokra utalva: „A festőnövények a régebbi időben igen fontos növények voltak, mert nagy jövedelmet szolgáltattak, melyeknek azonban ma már jelentőségük nincs, mert a Keletről származó olcsóbb festékek, különösen pedig a kőszénkátrányból elöállított anilinfestékek árukat annyira lenyomták, hogy a sok kézi munkát igénylő termelésük vagy semmi, vagy csak nagyon csekély jövedelmet szolgáltat, amiért azon vidékeken is, ahol egykor nagyobb arányokban termelték, vagy teljesen felhagytak termelésükkel, vagy csak szórványosan és kis területen termelik azokat. A felhozott okból céltalannak tartom az e csoportba tartozó növények termelésének ismertetését."

A sáfrányos szeklice, vagy más néven olajözön (Carthamus tinctorius L.) ElöÁzsiából származó régi kultúrnövény. A Középkorban a viráglevelek sárga festékanyaga miatt terjedt el a köztermesztésben. Ételszínezöként ma is használatos, mint a „vadsáfrány” adaléka. Magjából jó minőségü, többcélú olaj nyerhető. A mag olaja mintegy 90\%-ban telítetlen zsírsavakból áll, melyek közül 70-75\%-ban meghatározó a linolsav. Az olajpogácsa fehérjében gazdag, az olaja pedig étkezési célokra kiválóan alkalmas. A hosszantartó nemesítési munka eredményeképpen, mint olajnövény terjed az USA-ban és Európa szárazabb vidékein, különösen Spanyolországban. Magtermése elérheti a 4 t/ha mennyiséget. A növény hö-, szárazság- és sótürő (PRJANISNYIKOV, 1931; METCALFE \& ELKINS, 1980; GEISLER, 1988).

PRJANISNYIKOV (1931) „,Szaflor” néven említi az olajözönt, mely főként Turkesztánban és a Kaukázusban ismert. Olajnövényként gyakran a napraforgót helyettesíti. HEIM és munkatársai (1985) szerint É-Dakotában, az USA Nyugati Nagy Síkságán 1928 óta folynak kísérletek a „,safflower” néven ismert olajözönnel, mely a száraz búzaövezet természeti körülményeihez adaptálódott. Trágyaigénye függhet az elérhető termés nagyságától, a forgóban elfogadott helyétől. Meghatározó természetesen a termőhely talajának tápelemkészlete. Mint olajnövény nemcsak N- és P-, hanem K-igényével is kitünik. A termések az USA-ban 0,5-2,5 t/ha között inga-

Postai cím: KÁDÁR IMRE, MTA Talajtani és Agrokémiai Kutatóintézet, 1022 Budapest, Herman Ottó út 15.E-mail: kadar@rissac.hu 
doznak, elsősorban a csapadéktól függően. Száraz években a termések alacsonyak, ezért ahol lehet célszerü öntözni. A csíranövény érzékeny a nagyobb $\mathrm{N}$-adagokra, különösen a karbamid formára.

KEREKES (1969) a gyógynövények között tárgyalja az olajözön termesztését. Hangsúlyozza, hogy a trágyázott kapásnövények a legjobb előveteményei. Évtizedek óta Nagybánhegyes környékén és Békés megye más területein jó minőségü, meleg fekvésủ talajokon foglalkoztak termesztésével. Szerinte kataszteri holdanként $70-110 \mathrm{~kg}$ száraz virág és $0,6-1,0 \mathrm{t}$ mag gyüjthető.

Újabban ANTAL (1987) ad útmutatást e növénnyel összefüggésben: „Az olajözön igényli a talaj tápanyaggal való feltöltöttségét, de ugyanakkor jó tápanyagfeltáró növény. Alaptrágyának hektáronként 35-40 kg N-t, 40-60 kg $\mathrm{P}_{2} \mathrm{O}_{5}$-ot és 50-70 $\mathrm{kg} \mathrm{K}_{2} \mathrm{O}$-ot kapjon ősszel. A 2,5\%-nál kevesebb humuszt tartalmazó talajon a tavaszi magágyba további $20-25 \mathrm{~kg} / \mathrm{ha} \mathrm{N}$-t adjunk!” A szerző szerint az olajözön talajigénye alapján a mély rétegủ és jó vízgazdálkodású csernozjomok, valamint a termékenyebb humuszos homoktalajok növénye. Mivel meleg- és napfényigényes a DélAlföldön és Dél-Baranyában termeszthető sikeresebben.

Munkánk célja, hogy olyan mütrágyázási tartamkísérletben teszteljük az olajözön trágyareakcióját, ahol már jól elkülönült tápelem-ellátottsági szintek alakultak ki a talajban. Mivel ez a növény elsősorban a gyengébb homoktalajokon lehet versenyképes a napraforgóval szemben, az MTA Talajtani és Agrokémiai Kutatóintézet Örbottyáni Kísérleti Telepén, Duna-Tisza közi karbonátos homokon állítottuk tartamkísérletbe.

Korábbi közleményben (KÁDÁR, 2005) bemutattuk a mütrágyázásnak e növény fejlődésére, aratáskori terméselemeire, a kaszatok olajtartalmára és zsírsavösszetételére gyakorolt hatását. Megállapítottuk, hogy az aszályos 1990-es évben a kaszattermés a 20 éve trágyázatlan talajon mindössze $200 \mathrm{~kg} / \mathrm{ha}$ mennyiséget tett ki. A Ktrágyázás részben ellensúlyozta a vízhiányt és a magtermés $600 \mathrm{~kg} / \mathrm{ha}$ fölé emelkedett. Ezzel együtt mérsékelten, de igazolhatóan nőtt az olajtartalom is, az olajhozam 3,5-szeresére emelkedett a kontrollhoz képest. A szeklice versenyképesnek minösülhet hasonló viszonyok között 3-4:1 = búza-rozs:szeklice magtermés-arányokat feltételezve, ugyanis e talajon 1990-ben 1-2 t/ha kalászos szemterméseket kaptunk mütrágyázási kísérleteinkben.

A bőséges K-trágyázás (megfelelő NP alapon) egyaránt előnyösnek mutatkozott a növény kezdeti fejlődésére, kelésére, borítottságára, korai virágzására, magasságára, az elágazások és a gubók számára, az ezerkaszat tömegére, valamint a fö/melléktermés arányára, az ún. harvest indexre. A termékenyebb trágyázott talajon gyors és egyenletes volt a kelés, nött a zöld levéltömeg és a növények közel 2 héttel korábban érték el a generatív szakaszt jelentő virágzás állapotát (KÁDÁR, 2005).

\section{Anyag és módszer}

Az MTA TAKI Örbottyáni Kísérleti Telepe a Duna-Tisza közi homokhátság északi részén, a Gödöllői-dombvidék pereméhez közel helyezkedik el. A talajvíz tükre 5-10 m mélyen található, a talajképződési folyamatokat, ill. a trágyahatásokat 
nem befolyásolja. A termőhely a homoktalajokra jellemzően rossz vízgazdálkodású, aszályérzékeny, heterogén tulajdonságú és NPK tápelemekben szegény. Kozák Mátyás 1970 öszén két párhuzamos mütrágyázási kísérletet állított be azonos 10-10 kezeléssel és 4-4 ismétléssel, azaz összesen 40-40 db egyenként $50 \mathrm{~m}^{2}$-es parcellával kéttényezős véletlen blokk elrendezésben (KOZÁK, 1977; KozÁK \& SzEMES, 1984).

A kísérlet talaja csernozjom jellegü humuszos homok, 60-70 cm humuszos szinttel. A szántott réteg $\mathrm{CaCO}_{3}$ - és humusztartalma $1 \%$ körüli. $\mathrm{A} \mathrm{pH}\left(\mathrm{H}_{2} \mathrm{O}\right) 7,3$, a $\mathrm{pH}(\mathrm{KCl}) 7,0$ átlagosan. A P- $\left(0,60\right.$ és $120 \mathrm{~kg} \mathrm{P}_{2} \mathrm{O}_{5} /$ ha/év $)$ és K-mütrágyákat $(0$, $100,200,300$ és $400 \mathrm{~kg} \mathrm{~K}_{2} \mathrm{O} / \mathrm{ha} /$ év), valamint a nitrogén ( 0,80 és $\left.160 \mathrm{~kg} \mathrm{~N} / \mathrm{ha} / \mathrm{e} v\right)$ felét ősszel szántás előtt, másik felét tavasszal szórtuk ki 25\%-os pétisó, 18\%-os szuperfoszfát és 50\%-os kálisó formájában. A kísérletek különösen a K-hatásgörbék tanulmányozására alkalmasak kétféle NP-szinten.

A 20. év után talajmintavételre került sor a szántott rétegből, az átlagminták 20 20 lefúrás anyagát tartalmazták parcellánként. E mintákban meghatároztuk a könynyen oldható PK-tartalmakat az EGNÉR és munkatársai (1960) által ajánlott ALmódszerrel. Termésbecslés és növényanalízis céljaira növénymintákat vettünk 30$40 \mathrm{~cm}$ magasságban 1990. június 25 -én és virágzás kezdetén július 26-án, valamint szeptember 3-án aratáskor. A júniusi és júliusi minta 20-20 db elágazás alatti levelet, míg az aratáskori 20-20 db teljes föld feletti növényt jelentett. Mértük a minták friss és légszáraz tömegét, majd cc. $\mathrm{H}_{2} \mathrm{SO}_{4}+\mathrm{cc} . \mathrm{H}_{2} \mathrm{O}_{2}$ roncsolást követően meghatároztuk fontosabb makro- és mikroelem-tartalmukat. Külön vizsgáltuk a szem, szalma és a pelyva összetételét. Az analízisekhez 2-2 ismétlés anyagát egyesítettük, így összesen 100 mintát elemeztünk 10 elemre.

A sáfrányos szeklice magmintáiban a Növényolaj- és Mosószeripari Kutatóintézet meghatározta parcellánként az 1000-mag tömegét, olaj \%-ot, valamint a zsírsavösszetételt is. Ami a csapadék-ellátottságot illeti, áprilisban 36, májusban 16, júniusban 70, júliusban 25, augusztusban $18 \mathrm{~mm}$ esőt kapott a terület. Rendkívül száraz, aszályos volt a május, július és augusztus. Ilyenkor a növények - különösen a tavaszi vetésủek - a nyári hónapokban gyakran elszáradnak, kiégnek homoktalajon. A nyári hónapokban lehullott csapadék $120 \mathrm{~mm}$-rel maradt el a sokévi átlagtól 1990-ben.

\section{Kísérleti eredmények}

A kezelések hatását a talaj szántott rétegének ammónium-laktát- (AL-) oldható PK-készletére, valamint a szeklice kaszattermésére az 1. táblázat foglalja össze. Az adatokból látható, hogy a 20 éve trágyázásban nem részesült kontrolltalajon mind az AL- $\mathrm{K}_{2} \mathrm{O}$, mind az AL- $\mathrm{P}_{2} \mathrm{O}_{5}$ készlet a szántott rétegben rendkívül kicsi. Korábbi vizsgálataink eredményeképpen megállapítottuk, hogy hasonló meszes homoktalaj kielégítően ellátottnak minősülhet, ha az AL- $\mathrm{P}_{2} \mathrm{O}_{5}$ készlete a 160-200, míg az AL$\mathrm{K}_{2} \mathrm{O}$ készlete a 100-150 mg/kg tartományba emelkedik (KÁDÁR, 1992).

A szeklice is meghálálja a talaj oldható PK-ellátottságának kielégítő szintre való emelését, a $150 \mathrm{mg} / \mathrm{kg}$ körüli $\mathrm{AL}-\mathrm{P}_{2} \mathrm{O}_{5}$, ill. $\mathrm{AL}-\mathrm{K}_{2} \mathrm{O}$ jelenlétét a szántott rétegben, 
1. táblázat

Mütrágyázás hatása a talaj szántott rétegének AL-oldható PK-készletére és a szeklice termésére a kísérlet 20. évében (Meszes homoktalaj, Örbottyán, 1990)

\begin{tabular}{|c|c|c|c|c|c|c|c|c|}
\hline \multicolumn{3}{|c|}{ (1) Mütrágyázás } & \multicolumn{2}{|c|}{ (2) AL-oldható } & \multicolumn{4}{|c|}{ (3) Légszáraz termés 1990. szeptember 3-án } \\
\hline $\mathrm{N}$ & $\mathrm{P}_{2} \mathrm{O}_{5}$ & $\mathrm{~K}_{2} \mathrm{O}$ & $\mathrm{K}_{2} \mathrm{O}$ & $\mathrm{P}_{2} \mathrm{O}_{5}$ & $\begin{array}{c}\text { (4) } \\
\text { Kaszat }\end{array}$ & $\begin{array}{c}(5) \\
\text { Szalma }\end{array}$ & $\begin{array}{c}(6) \\
\text { Pelyva }\end{array}$ & $\begin{array}{c}\text { (7) } \\
\text { Összesen }\end{array}$ \\
\hline \multicolumn{3}{|c|}{$\mathrm{kg} / \mathrm{ha} / \mathrm{év}$} & \multicolumn{2}{|c|}{$\mathrm{mg} / \mathrm{kg}$} & \multicolumn{4}{|c|}{$\mathrm{t} / \mathrm{ha}$} \\
\hline 0 & 0 & 0 & 54 & 76 & 0,20 & 0,44 & 0,39 & 1,03 \\
\hline 80 & 60 & 0 & 46 & 117 & 0,20 & 0,66 & 0,48 & 1,34 \\
\hline 80 & 60 & 100 & 61 & 118 & 0,36 & 0,72 & 0,52 & 1,60 \\
\hline 80 & 60 & 200 & 81 & 124 & 0,43 & 0,90 & 0,57 & 1,90 \\
\hline 80 & 60 & 300 & 99 & 109 & 0,56 & 1,19 & 0,74 & 2,50 \\
\hline 160 & 120 & 0 & 45 & 177 & 0,26 & 0,80 & 0,64 & 1,70 \\
\hline 160 & 120 & 100 & 58 & 205 & 0,44 & 1,18 & 0,79 & 2,41 \\
\hline 160 & 120 & 200 & 86 & 208 & 0,45 & 1,06 & 0,70 & 2,21 \\
\hline 160 & 120 & 300 & 111 & 179 & 0,51 & 1,13 & 0,76 & 2,40 \\
\hline 160 & 120 & 400 & 133 & 183 & 0,64 & 1,44 & 0,89 & 2,97 \\
\hline \multirow{2}{*}{\multicolumn{3}{|c|}{$\begin{array}{l}\text { a) } \mathrm{SzD}_{5 \%} \\
\text { b) Átlag }\end{array}$}} & 14 & 18 & 0,16 & 0,49 & 0,28 & 0,88 \\
\hline & & & 77 & 150 & 0,40 & 0,95 & 0,65 & 2,01 \\
\hline
\end{tabular}

valamint a $80-100 \mathrm{~kg} / \mathrm{ha} \mathrm{N}$-adag biztosítását hasonló körülmények között. A homoktalajok termékenységét, mivel K-készletük eredendően kicsi, döntően befolyásolhatjuk K-trágyázással. Az olajözön K-igénye kifejezetté válhat nagyobb termésszinten, irodalmi utalások szerint elérheti a 200-300 kg/ha mennyiséget (HEIM et al., 1985).

Az összes föld feletti légszáraz hozamot tekintve megállapítható - a bevezetésben előadottakat kiegészítve -, hogy a kaszattermés csak kisebb részét teszi ki a teljes betakarítható termésnek. Terméscsökkenést sem az önmagában adott NPtrágyázás, sem az NP-trágyákkal együtt adott nagymennyiségủ K-trágya nem okozott. Sőt, utóbbi esetben értük el a termésmaximumokat (1. táblázat).

A levélanalízis eredményei szerint a kontrollhoz viszonyítva nött a levelek $\mathrm{P} \%$-a az NP-szinteken és mérséklődött a K-adagolással, különösen az idősebb levelekben. A javuló K-kínálattal a K\% 2-3-szorosára emelkedett, míg a kationantagonizmus eredményeképpen a Ca- és Mg-koncentráció visszaesett mindkét vizsgált időpontban. Az elöregedéssel nőtt a kalcium túlsúlya a káliummal szemben. Ami a diagnosztikai célú optimumokat illeti, a $0,3-0,4 \%$ közötti P (ill. a fiatal levélben a 4$5 \%$ ), virágzás elején a 3-4\% K tükrözheti a kielégítő tápláltsági állapotot. A kiegyensúlyozott $\mathrm{K} / \mathrm{P}$ arány a fiatal levelekben 10-15, virágzás elején 9-12 körül ingadozhat. A meszes termőhely viszonyait figyelembe véve a $\mathrm{K} / \mathrm{Ca}$ hányados optimuma 2-3, míg a K/Mg hányadosé 10-15 közöttire becsülhetö a fiatal levelekben (2. táblázat).

A nagyobb termésekhez 3-4\% N kötődött a levélben, tehát az optimális N/P arány 10 körüli értéknek adódik. A növényi szervek közötti átlagos elemtartalmakat vizsgálva azt találjuk, hogy a N, P, Mg és Zn elemek föként a kaszatban akkumulá- 
2. táblázat

Mütrágyázás hatása a sáfrányos szeklice légszáraz levelének összetételére (Meszes homoktalaj, Örbottyán, 1990)

\begin{tabular}{|c|c|c|c|c|c|c|c|c|c|}
\hline \multicolumn{3}{|c|}{ (1) Mütrágyázás, kg/ha/év } & $P$ & $\mathrm{~K}$ & $\mathrm{Ca}$ & $\mathrm{Mg}$ & $\mathrm{K} / \mathrm{Ca}$ & $\mathrm{K} / \mathrm{Mg}$ & $\mathrm{K} / \mathrm{P}$ \\
\hline $\mathrm{N}$ & $\mathrm{P}_{2} \mathrm{O}_{5}$ & $\mathrm{~K}_{2} \mathrm{O}$ & \multicolumn{4}{|c|}{$\%$} & \multicolumn{3}{|c|}{ (2) arány } \\
\hline \multicolumn{10}{|c|}{ A. 30-40 cm magasságú növényállomány } \\
\hline 0 & 0 & 0 & 0,25 & 1,62 & 3,53 & 0,54 & 0,5 & 3,0 & 6,5 \\
\hline 80 & 60 & 0 & 0,29 & 1,50 & 3,09 & 0,56 & 0,5 & 2,7 & 5,2 \\
\hline 80 & 60 & 100 & 0,29 & 3,78 & 3,64 & 0,52 & 1,0 & 7,3 & 13,0 \\
\hline 80 & 60 & 200 & 0,29 & 3,98 & 2,39 & 0,37 & 1,7 & 10,8 & 13,7 \\
\hline 80 & 60 & 300 & 0,26 & 4,25 & 2,28 & 0,33 & 1,9 & 12,9 & 16,3 \\
\hline 160 & 120 & 0 & 0,37 & 1,39 & 3,31 & 0,70 & 0,4 & 2,0 & 3,8 \\
\hline 160 & 120 & 100 & 0,39 & 2,83 & 3,05 & 0,45 & 0,9 & 6,3 & 7,3 \\
\hline 160 & 120 & 200 & 0,34 & 3,90 & 2,45 & 0,37 & 1,6 & 10,5 & 11,5 \\
\hline 160 & 120 & 300 & 0,36 & 4,65 & 2,23 & 0,34 & 2,1 & 13,7 & 12,9 \\
\hline 160 & 120 & 400 & 0,31 & 4,93 & 2,25 & 0,33 & 2,2 & 14,9 & 15,9 \\
\hline \multicolumn{3}{|c|}{ a) $\mathrm{SzD}_{5 \%}$} & 0,07 & 1,07 & 1,03 & 0,12 & 0,6 & 2,2 & 3,3 \\
\hline \multicolumn{3}{|c|}{ b) Átlag } & 0,31 & 3,28 & 2,82 & 0,45 & 1,3 & 8,4 & 10,6 \\
\hline \multicolumn{10}{|c|}{ B. Virágzás elején } \\
\hline 0 & 0 & 0 & 0,25 & 1,55 & 3,18 & 0,47 & 0,5 & 3,3 & 6,2 \\
\hline 80 & 60 & 0 & 0,32 & 1,14 & 3,60 & 0,66 & 0,3 & 1,7 & 3,6 \\
\hline 80 & 60 & 100 & 0,28 & 2,20 & 3,56 & 0,50 & 0,6 & 4,4 & 7,9 \\
\hline 80 & 60 & 200 & 0,30 & 2,83 & 2,89 & 0,41 & 1,0 & 6,9 & 9,4 \\
\hline 80 & 60 & 300 & 0,27 & 3,15 & 2,99 & 0,43 & 1,1 & 7,3 & 11,7 \\
\hline 160 & 120 & 0 & 0,40 & 0,89 & 4,08 & 0,77 & 0,2 & 1,2 & 2,2 \\
\hline 160 & 120 & 100 & 0,35 & 2,25 & 3,53 & 0,52 & 0,6 & 4,3 & 6,4 \\
\hline 160 & 120 & 200 & 0,32 & 2,90 & 2,68 & 0,41 & 1,1 & 7,1 & 9,1 \\
\hline 160 & 120 & 300 & 0,29 & 3,53 & 2,87 & 0,42 & 1,2 & 8,4 & 12,2 \\
\hline 160 & 120 & 400 & 0,28 & 3,45 & 2,48 & 0,38 & 1,4 & 9,1 & 12,3 \\
\hline \multirow{2}{*}{\multicolumn{3}{|c|}{$\begin{array}{l}\text { a) } \mathrm{SzD}_{5 \%} \\
\text { b) Átlag }\end{array}$}} & 0,07 & 0,34 & 0,58 & 0,10 & 0,3 & 0,8 & 12,2 \\
\hline & & & 0,30 & 2,39 & 3,18 & 0,50 & 0,8 & 5,4 & 8,1 \\
\hline
\end{tabular}

lódnak, míg a $\mathrm{K}, \mathrm{Ca}, \mathrm{Na}, \mathrm{Fe}$ és Mn elemek nagyobb tömege leszántáskor a melléktermékkel visszakerülhet a talajba. Az aggodalomra okot adó nitrátot a növény fiatal korban veszi fel és a vegetatív szervek akkumulálják, tárolják. A fotoszintézis, ill. a szárazanyag-képződés során a nitrát felhasználódik és a szemtermésben már csak $0,1 \mathrm{mg} / \mathrm{g}$ mennyiségben található (3. táblázat).

Az adatokból az is látható, hogy a $\mathrm{K}, \mathrm{Ca}, \mathrm{Na}, \mathrm{Fe}$ és Mn elemekben a vizsgált növényi szerveket tekintve legszegényebb volt a szem; N, P, Mg és Zn elemekben a szalma; míg a $\mathrm{K}, \mathrm{Ca}, \mathrm{Mg}$, Fe és Mn elemek legnagyobb készlete a levelekben, ill. $\mathrm{Cu}$ elem esetén a pelyvában volt található (3. táblázat).

Az aratáskori növényi szervek is jól jeleztek bizonyos változásokat a trágyázás hatására. A kontrollhoz viszonyítva hígult a $\mathrm{Ca}$ és Cu koncentrációja a szemtermés- 
3. táblázat

A sáfrányos szeklice átlagos tápelemtartalmának alakulása (Meszes homoktalaj, Örbottyán, 1990)

\begin{tabular}{|lc|c|c|c|c|c|}
\hline \multirow{2}{*}{$\begin{array}{c}\text { Elem jele és } \\
\text { mértékegysége }\end{array}$} & \multicolumn{5}{|c|}{ (2) Légszáraz növényi részek } \\
\cline { 2 - 7 } & Fiatal levél & $\begin{array}{c}(4) \\
\text { Idős levél }\end{array}$ & $\begin{array}{c}(5) \\
\text { Pelyva }\end{array}$ & $\begin{array}{c}(6) \\
\text { Szalma }\end{array}$ & $\begin{array}{c}(7) \\
\text { Szem }\end{array}$ \\
\hline $\mathrm{N}$ & $\%$ & 3,63 & 3,71 & 1,71 & 1,18 & 3,89 \\
$\mathrm{P}$ & $\%$ & 0,31 & 0,30 & 0,23 & 0,10 & 0,78 \\
$\mathrm{~K}$ & $\%$ & 3,28 & 2,39 & 1,08 & 0,69 & 0,71 \\
$\mathrm{Ca}$ & $\%$ & 2,82 & 3,18 & 1,85 & 1,59 & 0,17 \\
$\mathrm{Mg}$ & $\%$ & 0,45 & 0,50 & 0,23 & 0,19 & 0,34 \\
$\mathrm{Na}$ & $\mathrm{mg} / \mathrm{kg}$ & 136 & 111 & 126 & 203 & 104 \\
$\mathrm{Fe}$ & $\mathrm{mg} / \mathrm{kg}$ & 300 & 229 & 183 & 177 & 90 \\
$\mathrm{Mn}$ & $\mathrm{mg} / \mathrm{kg}$ & 153 & 150 & 47 & 49 & 18 \\
$\mathrm{Zn}$ & $\mathrm{mg} / \mathrm{kg}$ & 22 & 20 & 21 & 8 & 53 \\
$\mathrm{Cu}$ & $\mathrm{mg} / \mathrm{kg}$ & 7 & 6 & 12 & 8 & 11 \\
$\mathrm{NO}_{3}-\mathrm{N}$ & $\mathrm{g} / \mathrm{kg}$ & 1,67 & 0,67 & 0,55 & 0,20 & 0,10 \\
\hline
\end{tabular}

ben. A szárban tükröződött a $\mathrm{K} \%$ növekedése a javuló K-kínálattal és a $\mathrm{Mg} \%$ mérséklődése; a pelyvában pedig igazolható volt a K-trágyázás hatása a K-tartalom emelkedésén túl a $\mathrm{N}$-, $\mathrm{Ca}$ - és $\mathrm{NO}_{3}-\mathrm{N}$ készlet csökkenésén. Figyelemre méltó különösen a $\mathrm{NO}_{3}$-N drasztikus növekedése a nagyobb NK-kezelésben és látványos esése $0,54 \mathrm{mg} / \mathrm{kg}$ értékről $0,10 \mathrm{mg} / \mathrm{kg}$ értékre a maximális termést adó, ill. maximális mütrágyát kapott parcellákon (4. táblázat).

\section{4. táblázat}

Mütrágyázás hatása a légszáraz sáfrányos szeklice tápelemtartalmára aratáskor (Meszes homoktalaj, Örbottyán, 1990)

\begin{tabular}{|c|c|c|c|c|c|c|c|c|c|c|}
\hline \multicolumn{3}{|c|}{ (1) Mütrágyázás } & \multicolumn{2}{|c|}{ (2) Szemben } & \multicolumn{2}{|c|}{ (3) Szárban } & \multicolumn{4}{|c|}{ (4) Pelyvában } \\
\hline $\mathrm{N}$ & $\mathrm{P}_{2} \mathrm{O}_{3}$ & $\mathrm{~K}_{2} \mathrm{O}$ & $\mathrm{Ca}$ & $\mathrm{Cu}$ & $\mathrm{K}$ & $\mathrm{Mg}$ & $\mathrm{N}$ & $\mathrm{K}$ & $\mathrm{Ca}$ & $\mathrm{NO}_{3}-\mathrm{N}$ \\
\hline \multicolumn{3}{|c|}{$\mathrm{kg} / \mathrm{ha} / \mathrm{év}$} & $\%$ & $\mathrm{mg} / \mathrm{kg}$ & \multicolumn{2}{|c|}{$\%$} & \multicolumn{3}{|c|}{$\%$} & $\%$ \\
\hline 0 & 0 & 0 & 0,21 & 16 & 0,39 & 0,22 & 1,67 & 0,67 & 1,87 & 0,16 \\
\hline 80 & 60 & 0 & 0,20 & 13 & 0,36 & 0,28 & 1,84 & 0,63 & 2,04 & 0,39 \\
\hline 80 & 60 & 100 & 0,17 & 12 & 0,58 & 0,20 & 1,61 & 1,11 & 1,78 & 0,19 \\
\hline 80 & 60 & 200 & 0,17 & 11 & 0,71 & 0,17 & 1,66 & 1,37 & 1,73 & 0,15 \\
\hline 80 & 60 & 300 & 0,15 & 12 & 0,99 & 0,17 & 1,53 & 1,43 & 1,71 & 0,11 \\
\hline 160 & 120 & 0 & 0,22 & 11 & 0,35 & 0,28 & 2,23 & 0,60 & 2,29 & 0,54 \\
\hline 160 & 120 & 100 & 0,16 & 9 & 0,59 & 0,18 & 1,90 & 1,06 & 1,98 & 0,17 \\
\hline 160 & 120 & 200 & 0,16 & 11 & 0,71 & 0,16 & 1,53 & 1,18 & 1,76 & 0,13 \\
\hline 160 & 120 & 300 & 0,15 & 9 & 1,03 & 0,15 & 1,69 & 1,33 & 1,72 & 0,10 \\
\hline 160 & 120 & 400 & 0,14 & 9 & 1,17 & 0,13 & 1,47 & 1,48 & 1,61 & 0,10 \\
\hline \multirow{2}{*}{\multicolumn{3}{|c|}{$\begin{array}{l}\text { a) } \mathrm{SzD}_{5 \%} \\
\text { b) Átlag }\end{array}$}} & 0,03 & 2 & 0,26 & 0,06 & 0,31 & 0,13 & 0,13 & 0,18 \\
\hline & & & 0,17 & 11 & 0,69 & 0,19 & 1,71 & 1,08 & 1,85 & 0,20 \\
\hline
\end{tabular}


A kicsi kaszattermések elemfelvétele is minimális maradt, azonban a kontrollés a legjobb termésủ kezelések között többszörös különbségek adódtak. Így pl. a minimum-maximum értékek az alábbiak szerint változtak: $\mathrm{N} 8$ és 25, P 1,6 és 5,2, $\mathrm{K} 1,5$ és 4,8, Ca 0,4 és 0,8, Mg 0,7 és 2,2 kg/ha; Fe 18 és 56, Mn 3 és 13, Zn 11 és $35, \mathrm{Cu} 3$ és $6 \mathrm{~g} / \mathrm{ha}$ (5. táblázat).

\section{5. táblázat}

Mütrágyázás hatása a sáfrányos szeklice szemtermésének tápelemfelvételére (Meszes homoktalaj, Örbottyán, 1990)

\begin{tabular}{|c|c|c|c|c|c|c|c|c|c|c|c|}
\hline $\mathrm{N}$ & $\mathrm{P}_{2} \mathrm{O}_{5}$ & $\mathrm{~K}_{2} \mathrm{O}$ & $\mathrm{N}$ & $\mathrm{P}$ & $\mathrm{K}$ & $\mathrm{Ca}$ & $\mathrm{Mg}$ & $\mathrm{Fe}$ & $\mathrm{Mn}$ & $\mathrm{Zn}$ & $\mathrm{Cu}$ \\
\hline \multicolumn{3}{|c|}{$\mathrm{kg} / \mathrm{ha} / \mathrm{e} \mathrm{v}$} & \multicolumn{5}{|c|}{$\mathrm{kg} / \mathrm{ha}$} & \multicolumn{4}{|c|}{$\mathrm{g} / \mathrm{ha}$} \\
\hline 0 & 0 & 0 & 8 & 1,6 & 1,5 & 0,42 & 0,72 & 19 & 3,9 & 12 & 3,2 \\
\hline 80 & 60 & 0 & 9 & 1,7 & 1,5 & 0,38 & 0,73 & 18 & 3,0 & 11 & 2,4 \\
\hline 80 & 60 & 100 & 13 & 2,6 & 2,4 & 0,62 & 1,19 & 33 & 6,3 & 19 & 4,4 \\
\hline 80 & 60 & 200 & 15 & 3,0 & 2,9 & 0,70 & 1,29 & 42 & 8,7 & 20 & 4,7 \\
\hline 80 & 60 & 300 & 21 & 4,2 & 4,2 & 0,80 & 1,87 & 46 & 9,4 & 29 & 6,7 \\
\hline 160 & 120 & 0 & 10 & 2,1 & 1,7 & 0,55 & 0,87 & 24 & 4,8 & 14 & 2,8 \\
\hline 160 & 120 & 100 & 17 & 3,5 & 3,1 & 0,68 & 1,50 & 34 & 6,5 & 19 & 3,8 \\
\hline 160 & 120 & 200 & 17 & 3,5 & 3,2 & 0,71 & 1,46 & 41 & 9,2 & 22 & 4.7 \\
\hline 160 & 120 & 300 & 21 & 4,1 & 3,9 & 0,77 & 1,83 & 46 & 9,6 & 29 & 4,4 \\
\hline 160 & 120 & 400 & 25 & 5,2 & 4,8 & 0,84 & 2,24 & 56 & 13,0 & 35 & 5,8 \\
\hline \multirow{2}{*}{\multicolumn{3}{|c|}{$\begin{array}{l}\text { a) } \mathrm{SzD}_{5 \%} \\
\text { b) Átlag }\end{array}$}} & 7 & 1,4 & 1,2 & 0,24 & 0,64 & 13 & 2,9 & 10 & 1,8 \\
\hline & & & 16 & 3,1 & 2,9 & 0,65 & 1,37 & 36 & 7,4 & 21 & 4,3 \\
\hline
\end{tabular}

\section{6. táblázat}

Mütrágyázás hatása a sáfrányos szeklice összes föld feletti termésével felvett tápelemek mennyiségére aratáskor (Meszes homoktalaj, Örbottyán, 1990)

\begin{tabular}{|c|c|c||c|c|c|c|c|c|c|c|c|}
\hline $\mathrm{N}$ & $\mathrm{P}_{2} \mathrm{O}_{5}$ & $\mathrm{~K}_{2} \mathrm{O}$ & $\mathrm{N}$ & $\mathrm{P}$ & $\mathrm{K}$ & $\mathrm{Ca}$ & $\mathrm{Mg}$ & $\mathrm{Fe}$ & $\mathrm{Mn}$ & $\mathrm{Zn}$ & $\mathrm{Cu}$ \\
\hline \multicolumn{3}{|c||}{$\mathrm{kg} / \mathrm{ha} / \mathrm{év}$} \\
\hline 0 & 0 & 0 & 20 & 3,2 & 6 & 8 & 2,6 & 156 & 41 & 24 & 12 \\
80 & 60 & 0 & 27 & 3,9 & 7 & 12 & 3,5 & 220 & 56 & 27 & 13 \\
80 & 60 & 100 & 28 & 4,8 & 10 & 10 & 3,8 & 253 & 65 & 36 & 16 \\
80 & 60 & 200 & 32 & 5,6 & 17 & 15 & 4,1 & 265 & 71 & 39 & 18 \\
80 & 60 & 300 & 46 & 7,5 & 27 & 19 & 5,7 & 457 & 96 & 57 & 26 \\
160 & 120 & 0 & 37 & 5,3 & 8 & 17 & 4,6 & 297 & 94 & 34 & 16 \\
160 & 120 & 100 & 46 & 7,5 & 18 & 21 & 5,5 & 364 & 91 & 44 & 24 \\
160 & 120 & 200 & 41 & 6,7 & 19 & 19 & 4,7 & 389 & 92 & 45 & 23 \\
160 & 120 & 300 & 47 & 7,5 & 26 & 19 & 5,2 & 357 & 104 & 55 & 22 \\
160 & 120 & 400 & 53 & 9,4 & 35 & 20 & 6,1 & 415 & 120 & 56 & 28 \\
\multicolumn{2}{|c|}{ a) $\mathrm{SzD}_{5 \%}$} & & 13 & 2,0 & 43 & 9 & 1,2 & 96 & 23 & 12 & 6 \\
b) Átlag & & 38 & 5,6 & 18 & 27 & 4,6 & 316 & 83 & 42 & 19 \\
\hline
\end{tabular}


Az összes föld feletti terméssel (szem + szalma + pelyva) felvett elemek menynyisége 20-53 kg N, 6-35 kg K, 8-20 kg Ca, 3,2-9,4 kg P, 2,6-6,1 kg Mg, ill. 156$415 \mathrm{~g} \mathrm{Fe}, 41-120 \mathrm{~g} \mathrm{Mn}, 24-56 \mathrm{~g} \mathrm{Zn}$ és 12-28 g Cu mennyiséget tett ki hektáronként a kezelések függvényében 1990-ben (6. táblázat).

A szeklice átlagos és fajlagos elemfelvételéről a 7. táblázat adatai tájékoztatnak. Ami az $1 \mathrm{t}$ szem és a hozzá tartozó melléktermés elő́llításához szükséges elemek

\section{7. táblázat}

Mütrágyázás hatása a sáfrányos szeklice átlagos és fajlagos tápelemfelvételére (Meszes homoktalaj, Örbottyán, 1990)

\begin{tabular}{|l|l|c|c|c|c|c|}
\hline \multicolumn{2}{|c|}{$\begin{array}{c}(1) \\
\text { Elem jele és } \\
\text { mértékegysége }\end{array}$} & $\begin{array}{c}(2) \\
\text { Szem }\end{array}$ & $\begin{array}{c}(3) \\
\text { Szár }\end{array}$ & $\begin{array}{c}(4) \\
\text { Pelyva }\end{array}$ & $\begin{array}{c}(5) \\
\text { Összesen }\end{array}$ & $\begin{array}{c}(6) \\
\text { Fajlagos* }\end{array}$ \\
\hline $\mathrm{N}$ & $\mathrm{kg} / \mathrm{ha}$ & 15,7 & 11,2 & 11,1 & 38,0 & 94 \\
$\mathrm{P}$ & $\mathrm{kg} / \mathrm{ha}$ & 3,1 & 1,0 & 1,5 & 5,6 & 14 \\
$\mathrm{~K}$ & $\mathrm{~kg} / \mathrm{ha}$ & 2,9 & 7,3 & 7,4 & 17,6 & 44 \\
$\mathrm{Ca}$ & $\mathrm{kg} / \mathrm{ha}$ & 0,6 & 14,9 & 11,9 & 27,4 & 68 \\
$\mathrm{Mg}$ & $\mathrm{kg} / \mathrm{ha}$ & 1,4 & 1,7 & 1,4 & 4,6 & 11 \\
$\mathrm{Na}$ & $\mathrm{g} / \mathrm{ha}$ & 41 & 192 & 78 & 311 & 768 \\
$\mathrm{Fe}$ & $\mathrm{g} / \mathrm{ha}$ & 36 & 163 & 118 & 316 & 780 \\
$\mathrm{Mn}$ & $\mathrm{g} / \mathrm{ha}$ & 7 & 45 & 31 & 83 & 205 \\
$\mathrm{Zn}$ & $\mathrm{g} / \mathrm{ha}$ & 21 & 8 & 14 & 42 & 103 \\
$\mathrm{Cu}$ & $\mathrm{g} / \mathrm{ha}$ & 4,3 & 7,4 & 7,8 & 19,4 & 48 \\
\hline
\end{tabular}

Megjegyzés: * 1 t szem + a hozzá tartozó melléktermék elöállításához szükséges tápelemek mennyisége

mennyiségét illeti, meglehetősen nagy fajlagos mutatókat találunk. Különösen, ha a kalászos gabonákkal történik az összehasonlítás. Példaképpen, az őszi árpa fajlagos elemigénye csernozjom talajon 25-30 kg N, 4-5 kg P és Ca, $2 \mathrm{~kg} \mathrm{Mg}$, 14-16 kg K; 150-200 g Fe, 50-60 g Mn, 30-40 g Zn, 6 g Cu (KÁDÁR, 2000). A szeklice tehát 24-szeresen meghaladhatja az említett öszi árpa fajlagos igényét, részben az igen tág (4-5-szörös) melléktermés/fötermés arány miatt.

Amennyiben hasonló kistermésủ olajnövényekkel történik az összehasonlítás, mint pl. a mák, a különbség elmosódik. Az $1 \mathrm{t}$ mákmag + a hozzá tartozó tok és szár átlagos elemigénye $83 \mathrm{~kg} \mathrm{~N}, 16 \mathrm{~kg} \mathrm{P}, 93 \mathrm{~kg} \mathrm{~K}, 65 \mathrm{~kg} \mathrm{Ca}, 11 \mathrm{~kg} \mathrm{Mg}, 800 \mathrm{~g} \mathrm{Fe}, 200 \mathrm{~g}$ $\mathrm{Mn}, 50 \mathrm{~g} \mathrm{Zn}$ és $30-40 \mathrm{~g} \mathrm{Cu}$ volt meszes csernozjom talajon (KÁDÁR et al., 2001). A vályog meszes csernozjomon a fajlagos K-tartalom a szeklicében több mint kétszeres, míg a Zn feleannyi volt, mint a mákban. A N, P, Ca, Mg, Fe és Mn elemek fajlagos készlete az eltérő termőhelyek és évek ellenére azonban nagyon közelálló (7. táblázat). 


\section{Összefoglalás}

Duna-Tisza közi meszes homoktalajon, Örbottyánban 1970-ben beállított NPKmütrágyázási tartamkísérlet 20. évében, 1990-ben vizsgáltuk a mütrágyázás hatását a sáfrányos szeklice elemfelvételére. A termőhely talaja a föbb tápelemekben $(\mathrm{N}, \mathrm{P}$, K) gyengén ellátott, a szántott réteg $1 \% \mathrm{CaCO}_{3}$-ot, $1 \%$ körüli humuszt és $5-10 \%$ agyagos részt tartalmaz. A talajvíz $8-10 \mathrm{~m}$ mélyen található, a terület aszályérzékeny.

A levonható föbb következtetések:

- A talajgazdagító PK-trágyázás nyomán a talaj ammónium-laktát- (AL-) oldható PK-készlete a „kielégítő” ellátottsági tartományba emelkedett. Az aszályos évben a magtermések kicsik maradtak, de az NP-szinteken a K-trágyázás részben ellensúlyozta a vízhiányt, a kaszattermés a kontrollkezelésben mért $200 \mathrm{~kg}$ /ha-ról 600 $\mathrm{kg} / \mathrm{ha}$ fölé emelkedett.

- A homoktalajok termékenységét döntően javíthatjuk K-trágyázással, mivel Kkészletük kicsi. Kívánatos a $150 \mathrm{mg} / \mathrm{kg}$ körüli $\mathrm{AL}-\mathrm{P}_{2} \mathrm{O}_{5^{-}}$, ill. AL- $\mathrm{K}_{2} \mathrm{O}-$ koncentráció elérése a szántott rétegben és emellett a kielégítő $\mathrm{N}$-ellátás biztosítása.

- A diagnosztikai célú optimumokat a fiatal levélben/lombban, 30-40 cm magas állományban a $4-5 \% \mathrm{~K}, 0,3-0,4 \% \mathrm{P}, 3-4 \% \mathrm{~N}$, ill. a $10-15 \mathrm{~K} / \mathrm{P}, 8-12 \mathrm{~N} / \mathrm{P}$ és az $1,0-$ $1,5 \mathrm{~K} / \mathrm{N}$ arány tükrözheti, melyhez a termésmaximumok kötődtek.

- A N, P, Mg és Zn elemek föként a kaszatban, míg a K, Ca, Na, Fe és Mn elemek döntően a melléktermékben dúsultak. Az $1 \mathrm{t}$ szem + a hozzá tartozó szalma és pelyva elemigénye átlagosan az alábbinak adódott: $94 \mathrm{~kg} \mathrm{~N}, 14 \mathrm{~kg} \mathrm{P}\left(32 \mathrm{~kg} \mathrm{P}_{2} \mathrm{O}_{5}\right)$, $44 \mathrm{~kg} \mathrm{~K}(53 \mathrm{~kg} \mathrm{~K} 2 \mathrm{O}), 68 \mathrm{~kg} \mathrm{Ca}, 11 \mathrm{~kg} \mathrm{Mg}, 768 \mathrm{~g} \mathrm{Na}, 780$ g Fe, $205 \mathrm{~g} \mathrm{Mn}, 103$ g $\mathrm{Zn}, 48 \mathrm{~g} \mathrm{Cu}$.

Kulcsszavak: mütrágyázás, talajvizsgálat, levéldiagnózis, termés, elemfelvétel

\section{Irodalom}

ANTAL J., 1987. Növénytermesztők zsebkönyve. Mezőgazdasági Kiadó. Budapest.

CSERHÁTI S., 1901. Általános és különleges növénytermelés. II. kötet. Czéh Sándor-féle Könyvnyomda. Magyar-Óvár.

EgNÉR, H., RIEHM, H. \& DOMINGO, W. R., 1960. Untersuchungen über die chemische Bodenanalyse als Grundlage für die Beurteilung des Nährstoffzustandes der Böden. II. K-Lantbr. Högsk. Ann. 26. 199-215.

GeISLER, G., 1988. Pflanzenbau. Verlag Paul Parey. Berlin-Hamburg.

HeIm, J. L. et al., 1985. Safflower Production. Coop. Ext. Serv. North Dakota State University. Fargo. 14 AGR. A-870.

KÁDÁR I., 1992. A növénytáplálás alapelvei és módszerei. MTA Talajtani és Agrokémiai Kutató Intézete. Budapest.

KÁDÁR I., 2000. Az öszi árpa (Hordeum vulgare L.) tápelemfelvétele karbonátos csernozjom talajon. Növénytermelés. 49. 547-559. 
KÁDÁR I., 2005. Mütrágyázás hatása a sáfrányos szeklice (Carthamus tinctorius L.) termésére és fejlödésére. Növénytermelés. (Megjelenés alatt.)

KÁDÁR I. et al., 2001. A mák (Papaver somniferum L.) mütrágyázása karbonátos vályog csernozjom talajon. II. Növénytermelés. 50. 67-478.

KEREKES J., 1969. Gyógynövénytermesztés. Mezőgazdasági Kiadó. Budapest.

KozÁK M., 1977. A kálium mütrágyázás hatása a búza, kukorica és takarmányborsó termésére és tápanyagtartalmára. Agrokémia és Talajtan. 26. 363-378.

KOZÁK M. \& SzEMES I., 1984. Összefüggések a lucerna tápanyag-ellátottsága, szénahozama és a karbonátos homoktalajok tulajdonságai között. Agrokémia és Talajtan. 33. 245-252.

Metcalfe, D. S. \& Elkins, D. M., 1980. Crop Production. Principles and Practices. $4^{\text {th }}$ ed. MacMillan Publishing Co. Inc., New York.

PRJANiSNYIKOV, D. N., 1931. Csasztnoe zemledelije. In: Izbrannüe szocsinenija. Tom. vtoroj. Izdatel'sztvo „Kolosz”. Moszkva. 1965.

Érkezett: 2006. szeptember 5. 


\title{
Effect of mineral fertilization on the element uptake of safflower (Carthamus tinctorius L.)
}

\author{
I. KÁDÁR \\ Research Institute for Soil Science and Agricultural Chemistry of the \\ Hungarian Academy of Sciences, Budapest
}

\section{Summary}

The effect of mineral fertilizer on the element uptake of safflower was examined in 1990 , in the $20^{\text {th }}$ year of a long-term NPK mineral fertilization experiment set up on calcareous sandy soil in Örbottyán in 1970. The soil of the experimental location was poorly supplied with macronutrients (NPK), and the ploughed layer contained 1\% $\mathrm{CaCO}_{3}$, around $1 \%$ humus and 5-10\% clay. The groundwater was located at a depth of $8-10 \mathrm{~m}$ and the area was prone to drought.

The following conclusions could be drawn from the results:

- As the result of soil-enriching PK fertilization the ammonium lactate (AL)-soluble PK reserves of the soil increased, reaching the "satisfactory" supply category. Due to drought, seed yields were low, but at each NP level K fertilization was able to partially compensate for water deficiency, with a rise in seed yield from $200 \mathrm{~kg} / \mathrm{ha}$ in the control treatment to over $600 \mathrm{~kg} / \mathrm{ha}$.

- The fertility of sandy soils can be decisively improved by $\mathrm{K}$ fertilization, as they have low $\mathrm{K}$ reserves. AL- $\mathrm{P}_{2} \mathrm{O}_{5}$ and $\mathrm{AL}-\mathrm{K}_{2} \mathrm{O}$ concentrations of around $150 \mathrm{mg} / \mathrm{kg}$ should be achieved in the ploughed layer, together with satisfactory supplies of $\mathrm{N}$.

- Maximum yields were obtained with nutrient contents of $4-5 \% \mathrm{~K}, 0.3-0.4 \% \mathrm{P}$ and $3-4 \% \mathrm{~N}$, and nutrient ratios of $10-15 \mathrm{~K} / \mathrm{P}, 8-12 \mathrm{~N} / \mathrm{P}$ and $1.0-1.5 \mathrm{~K} / \mathrm{N}$ in young leaves/foliage at a plant height of $30-40 \mathrm{~cm}$, which can thus be used as optimum levels for diagnostic purposes.

- The nutrients $\mathrm{N}, \mathrm{P}, \mathrm{Mg}$ and $\mathrm{Zn}$ were concentrated primarily in the seeds, and $\mathrm{K}$, $\mathrm{Ca}, \mathrm{Na}, \mathrm{Fe}$ and $\mathrm{Mn}$ in the by-products. The element requirements of $1 \mathrm{t}$ seed + relevant straw and husks were found to be $94 \mathrm{~kg} \mathrm{~N}, 14 \mathrm{~kg} \mathrm{P}\left(32 \mathrm{~kg} \mathrm{P}_{2} \mathrm{O}_{5}\right), 44 \mathrm{~kg} \mathrm{~K}\left(53 \mathrm{~kg} \mathrm{~K}_{2} \mathrm{O}\right)$, $68 \mathrm{~kg} \mathrm{Ca}, 11 \mathrm{~kg} \mathrm{Mg}, 768 \mathrm{~g} \mathrm{Na}, 780 \mathrm{~g} \mathrm{Fe}, 205 \mathrm{~g} \mathrm{Mn}, 103 \mathrm{~g} \mathrm{Zn}$ and $48 \mathrm{~g} \mathrm{Cu}$.

Table 1. Effect of mineral fertilization on the AL-soluble PK content of the ploughed soil layer and the yield of safflower in the $20^{\text {th }}$ year of the experiment (Calcareous sandy soil, Örbottyán, 1990). (1) Mineral fertilization, kg/ha/year. a) $\operatorname{LSD}_{5 \%}$; b) Mean. (2) AL-soluble, mg/kg. (3) Air-dry yield on 3 September 1990, t/ha. (4) Seed. (5) Straw. (6) Husks. (7) Total.

Table 2. Effect of mineral fertilization on the composition of air-dry leaves of safflower (Calcareous sandy soil, Örbottyán, 1990). (1) Mineral fertilization, kg/ha/year. a) $\mathrm{LSD}_{5 \%}$; b) Mean. (2) Ratio. A. 30-40 cm high plant stand. B. At the beginning of flowering.

Table 3. Mean nutrient contents of safflower (Calcareous sandy soil, Örbottyán, 1990). (1) Element symbol and units. (2) Air-dry plant organs. (3) Young leaves. (4) Older leaves. (5) Husks. (6) Straw. (7) Seeds. 
Table 4. Effect of mineral fertilization on the nutrient content of air-dry safflower at harvest (Calcareous sandy soil, Örbottyán, 1990). (1) Mineral fertilization, kg/ha/year. a) $\mathrm{LSD}_{5 \%}$; b) Mean. (2) In the seed. (3) In the stem. (4) In the husks.

Table 5. Effect of mineral fertilization on the nutrient uptake of the seed yield of safflower (Calcareous sandy soil, Örbottyán, 1990).

Table 6. Effect of mineral fertilization on the total nutrient uptake of the aboveground yield of safflower at harvest (Calcareous sandy soil, Örbottyán, 1990).

Table 7. Effect of mineral fertilzsation on the mean and specific nutrient uptakes of safflower (Calcareous sandy soil, Örbottyán, 1990). (1) Element symbol and units. (2) Seed. (3) Stem. (4) Husks. (5) Total. (6) Specific*. Note: Quantity of nutrients required for the production of $1 \mathrm{t}$ seed + relevant by-products. 